\title{
Monitoring Financial Intermediaries with Subordinated Debt: A Dynamic Signal Model for Bank Risk
}

\author{
Gloria González-Rivera ${ }^{1}$ \\ University of California, Riverside \\ Department of Economics \\ Riverside, CA 92521 \\ David Nickerson \\ Colorado State University \\ Departments of Economics and Finance \\ Fort Collins, CO 80523-1771
}

\begin{abstract}
Regulatory proposals that require financial intermediaries to issue subordinated debt are based on the premise that transactions in the secondary market of subordinated debt can attenuate moral hazard on the part of management if secondary market prices are informative signals of the solvency risk of the intermediary. Owing to the proprietary nature of dealer prices and the liquidity of secondary transactions, the practical value of information provided by subordinated debt issues in isolation is questionable. Following the view articulated by Flannery (1998), we propose a multivariate dynamic risk signal that combines fluctuations in equity prices, subordinated debt and senior debt yields. The signal is envisioned as a complementary instrument for regulators and investors to monitor and assess in real time the risk profile of the issuing institution. The signal is constructed as a coincident indicator with the following characteristics: (1) it is stochastic because is based in a time series model of yield fluctuations and equity returns; (2) it is extracted from pricing data; (3) it monitors idiosyncratic risk of the intermediary because yields and equity returns are filtered from market conditions; and (4) it is predictable to a large degree because it is possible to construct a leading indicator based almost entirely on spreads to Treasury. We implement the signal with data of the Bank of America after its merger with Nations Bank in October 1, 1998, and with data of Banker's Trust up to its merger with the Deutsche Bank in November 1998. In the case of Bank of America, the signal points mainly to two events of uprising risk, one in January 2000 when the bank disclosed losses in its bond and interest-rate swaps portfolios, which grew to $\$ 5.3$ billions in the fourth quarter of 1999 from $\$ 3.7$ billion in the third quarter; and another in November 2000 when the bank wrote off $\$ 1.1$ billion for bad loans. In the case of Banker's Trust, the signal points to the period of October/November 1995 after the filing of federal racketeering charges against Banker's Trust; and October 1998 when the bank suffered substantial losses from its investments in emerging markets.
\end{abstract}

\footnotetext{
${ }^{1}$ Corresponding author: gloria.gonzalez@ucr.edu

The authors wish to acknowledge the comments and suggestions of Mark Flannery and the participants of the American Finance Association in Washington DC. Stevan Stevanovic provided outstanding research assistance. All errors remain our responsibility.
} 


\section{Introduction}

Academics, regulators and members of the business press have all expressed interest in the potential benefits of mandatory issues of subordinated debt in the surveillance of financial intermediaries. Wider dissemination of an intermediary's liability prices, assuming such prices respond to changes in its portfolio, should partially attenuate moral hazard on the part of management. Current subordinated debt proposals aim to achieve the following objectives: (1) improve direct market discipline by increasing funding costs if the intermediary increases the risk of its portfolio; (2) improve indirect market discipline, by augmenting the information available to other investors and to regulators, if debt prices in secondary markets respond to the solvency risk of the institution; (3) improve transparency and disclosure, which are needed to price risk accurately; (4) protect the deposit insurance fund because subordinated debt holders have claims subordinated to the deposit insurer; and (5) reduce regulatory forbearance, encouraging regulators to take prompt corrective actions.

However, the practical value of using subordinated debt yields to reveal the institution's risk has been questioned on at least two grounds. First, secondary markets for subordinated corporate debt are decentralized, being formed by independent dealers, and likely to reflect a variety of influences in addition to institutional risk. Consequently, pricing data is difficult to access, though pricing data from corporate bond transactions is becoming easier to obtain (see Edwards, Harris, and Piwowar, 2004). Second, existing empirical evidence on the responsiveness of subordinated debt yields to changes in the institution's risk is ambivalent. Both of these features compromise the practical relevance of subordinated debt to predicting bank risk.

This paper addresses these two critiques by constructing a multivariate dynamic signal that combines the behavior of equity prices, subordinated debt, and senior debt, issued by the financial intermediary. The common feature to these three prices is that they are claims on the assets of the institution, albeit with different priorities and consequently, they represent three different risks. Our indicator of bank risk is based on the information implicit in the joint claims. Based on our estimation results, the indicator is shown to have practical value and it should be understood as a complementary tool in the tool kit that is available to regulators and supervisors for evaluating the riskiness of banks and other financial intermediaries.

The motivation for our construction stems from both difficulties with current proposals for subordinated debt. First, we claim that market monitoring cannot rely on crosssectional models of subordinated debt yield spreads and that dynamic modeling of spreads provides a more valuable and practical tool to assess risk for regulators and investors. Secondly, we claim that equity price movements contain information about the bank's risk distinct from that revealed by subordinated debt and, when available, should be incorporated in a robust statistical model of surveillance. Furthermore, subordinated debt yield spreads are noisy signals of the institution's risk because they may capture more information (i.e. liquidity issues, state of the business cycle, etc.) than merely the idiosyncratic risk of the institution. Our multivariate dynamic signal captures joint 
movements in equity prices, subordinated debt yields, and senior debt yields and, consequently, can serve as a more reliable coincident indicator of institutional risk.

Most of the research that claims that subordinated debt yields are informative as measures of risk focuses on regression analysis for a cross section of banks (Hannan and Hanweck (1988), Avery, Belton and Goldberg (1988), Gorton and Santomero (1990), Flannery and Sorescu (1996), DeYoung, Flannery, Lang and Sorescu (2001)). Yields are regressed on different proxies for risk such as ratings, leverage ratio, and other accounting measures of performance. On average, those banks that are perceived as riskier are hypothesized to have larger observable subordinated yield spreads. ${ }^{2}$ Crosssectional studies cannot provide a relevant and prompt signal mechanism to regulators or market participants mainly for two reasons. First, they rely on public accounting measures that are announced in a quarterly basis; and secondly, even in the event that accounting measures could be provided with a higher frequency, the statistical association between yields and accounting measures does not imply that subordinated debt yields are more informative that accounting measures. We could just rely on these measures, instead of yields, to assess the risk of the institution. If subordinated debt policy claims to be a valuable mechanism to the regulator, it needs to be timely. Regulators need to assess risk in real time in order to take prompt corrective action. There is a need to switch from cross-sectional studies to dynamic studies. Fluctuations over time of subordinated debt yield spreads for each institution may be informative when we understand the dynamic process behind and we can discriminate fluctuations around the mean from surprise fluctuations.

Subordinated debt proposals also presume that yield spreads are more informative than equity prices. This presumption is largely based on the response to the stochastic properties of different investments exhibited by the call and put options respectively implicit in the equity and debt issued by the intermediary. ${ }^{3}$ If equity resembles a call option on the assets of the intermediary, while the purchase of risky debt issued by the intermediary involves a short position in a put option on those same assets, management, acting on behalf of shareholders, has an incentive to increase the risk of the assets held by the intermediary whenever such an increase is not immediately visible to debt holders. The efficacy of subordinated debt proposals relies on the timely response of the holders of unsecured and uninsured debt to such changes. However, empirical evidence suggests a more equivocal response of equity prices to such changes. This may be due to two opposing effects. The increased risk on the implicit option to default is mitigated by the influence of the intermediary's charter value on the incentives of shareholders and management and by the reduction in the flow of profits owing to increased costs of debt service. ${ }^{4}$ This equivocal response, however, does not imply that equity prices are

2 This finding is more prominent in the US data after 1986 when the FDIC emphasized the exposure of subordinated debt holders.

${ }^{3}$ Merton (1974) was the first to recognize the analogy between corporate equity and a call option on the assets of the firm, and between holding corporate debt and the issuance of a put option.

${ }^{4}$ See Keeley (1990) for a simple model of the incentive effects of charter value, and Repullo (2000), Bliss (2000), Repullo and Suarez (1998), and Dewatripont and Tirole (1994) for additional discussions of the relation between equity, debt and asset risk in the banking firm while Berger (1991), Gilbert (1990) and Flannery (1998) provide surveys of empirical evidence on equity prices and bank risk. Gilbert (1990), for 
insensitive to portfolio changes, nor does it imply that equity prices and the prices of unsecured debt are linearly dependent in the underlying sources of risk. The joint consideration of equity prices and debt prices may increase information about managerial portfolio choices, relative to the consideration of debt prices alone.

Based on these two arguments, we propose the construction of a multivariate dynamic signal that combines the behavior of equity prices, subordinated debt, and senior debt, issued by the financial institution. This coincident indicator is stochastic and unobservable and the empirical question becomes one of how to identify it and what are its dynamic properties. To this end, we filter each price from systematic risk, and we assume that each filtered price has two stochastic components, one is a common component that runs across the three series of prices and represent the value of the joint claim; and the other is an idiosyncratic or residual component that picks up particular features of each security. This construction relies on the design of a trivariate model, from which the common component, which is the institution's risk, can be extracted with standard algorithms for signal extraction, i.e. Kalman filter. For each institution, regulators and investors can calculate an expected risk signal that is based on the estimation of the coincident indicator. Furthermore, we construct a leading indicator based on the spreads and equity returns that can forecast very accurately the coincident indicator.

The organization of the paper is the following. In section 2, we review current proposals for mandatory subordinated debt issuance and discuss, more generally, the role of asset prices in bank surveillance. In section 3, we describe the building of a signal as a coincident indicator of institutional risk. In section 4, we show the detailed implementation of the risk signal with data from Bank of America, and propose a leading indicator of institutional risk. We also apply the same methodology to data from Banker's Trust to estimate its risk signal. Finally, in section 5 we conclude with a summary of our main findings and future extensions.

\section{Subordinated debt and bank surveillance}

Proposals to require banks and other financial intermediaries to issue long-term subordinated debt reflect a desire by regulators to increase the efficacy of price incentives in regulated financial markets. The presence of explicit deposit insurance, in the case of depository institutions, and the presumption of additional implicit public guarantees for all large intermediaries, removes the incentive of protected debtholders to monitor managerial decisions. Subordinated debt proposals aspire to create a class of creditors who retain this incentive. ${ }^{5}$ Assuming that the prices of subordinated debt are sensitive to the impact of managerial decisions on the probability of an institution's solvency,

example, summarizing eleven empirical studies of the response of bank equity prices to increased risk, finds a consistent negative response. Flannery (1998) and Hughes, Lang Moon and Pagano (1999) provide counterevidence, especially for highly leveraged large banks. Asness and Smirlock (1991) and Fenn and Cole (1994) provide evidence of a consistent negative response of equity prices to higher leverage and/or losses suffered, respectively, by real estate investment trusts and property liability insurance intermediaries.

${ }^{5}$ Since monitoring is a public good, investment in monitoring by subordinated debtholders will always be less than the efficient level in all but limited circumstances. 
subordinated debtholders can directly discipline portfolio risk by increasing the yields required to hold the debt of relatively riskier institutions and in so doing can also create beneficial informational externalities to other claimants and to regulators. ${ }^{6}$

Since large banks and other types of financial intermediaries already issue large volumes of uninsured debt, proponents of mandatory subordinated debt issuance make three related arguments based upon its generation of informational externalities which complement existing regulatory examinations. ${ }^{7}$ First, the operations of large banks are becoming increasingly complex and, consequently, more costly to directly monitor through accounting-based bank examinations. Second, owing to these costs, regulatory procedures are relatively coarse in their classification of institutional risk. Significant yield changes in subordinated debt could provide an additional and more sensitive source of information about such risk. Finally, owing to their visibility, such yield changes could also provide a credible source of discipline for regulators themselves, mitigating the possibilities that current examination procedures offer for regulatory forbearance. ${ }^{8}$

The essence of any useful role for subordinated debt, or other forms of uninsured debt, in providing either direct or indirect market discipline is, consequently, the responsiveness of the yield on these liabilities to changes in the risk of the issuing intermediary. Existing evidence on this responsiveness is, in general, equivocal. For example, Avery, Belton and Goldberg (1988) and Gorton and Santomero (1990) found in cross-sectional samples that various measures of bank solvency risk were relatively poor explanatory variables of risk premia on subordinated debentures issued during the early and mid 1980s by large bank holding companies. Flannery and Sorescu (1996) found a consistent positive relationship between these variables only after 1989. Baer and Brewer (1986), James (1990), Hannan and Hanweck (1988), Cargill (1989 and Keeley (1990) found that accounting measures of bank risk do, in general, exert some negative influence on the prices of large, uninsured CDs issued by various cross-sectional samples of large banks. Ellis and Flannery (1992) and Hancock and Kwast (2001), the only extant studies to apply time-series estimation to this question, find significant and more timely responses of yields, respectively on uninsured large bank CD's and subordinated debt issues by large bank holding companies, to measures of bank risk.

\footnotetext{
${ }^{6}$ These two types of effects respectively correspond to "direct" and "indirect" market discipline. The credibility of covenants insuring exposure of subordinated debt holders to loss from corporate bankruptcy is, consequently, essential to the success of any program of mandatory subdebt issuance.

${ }^{7}$ Since the total amount of uninsured debt issued by large banks in the US is already far larger than any proposed requirement for subdebt issuance, arguments in favor of the role of subdebt in enhancing direct market discipline, in contrast, rest on beneficial effects from enforced substitution of sub debt for other forms of uninsured debt. These include its relatively greater risk sensitivity, owing to longer average maturities; the ability to impose covenants on subdebt holders that preclude ex post public bailouts, and its role as a buffer to protect insured deposits and the BIF. See Bliss (2000), Calomiris (1999), Evanoff and Wall (2000), Haubrich (1998), Lang and Robertson (2002), Levonian (2001), Wall (1989), and Federal Reserve Board (2000) for a survey of such direct market discipline arguments.

${ }^{8}$ In this latter argument, subordinated debt might serve several useful roles, including (1) being publicly and cheaply observable signals of the market evaluation of institutional solvency risk; (2) augmenting accounting based "triggers" for prompt corrective action with market-generated ones; and (3) supplementing additive and accounting based capital charges with a market measure of overall portfolio risk.
} 
Overall, a consensus view, as articulated by Flannery (1998), is that equity prices and the prices of various types of debt liability do appear to respond to changes in institutional risk perceived by market participants. However, in isolation, no single asset price provides sufficiently comprehensive information to serve as a sufficient signal of bank risk to regulators or financial market participants. We turn now to the question of whether a time-series indicator, based on a set of different asset prices, might do so.

\section{Building a risk signal. A coincident indicator of institutional risk}

We assume that the capital structure of a corporation can be broadly divided into three categories: subordinate debt, senior debt, and equity. These three types of securities are claims, with different priority, in the assets of the corporation. Default arises when the value of the claims is larger than the value of the assets. In this case, senior bondholders have priority over subordinated debt holders, and these, in turn, have priority over stockholders, on the distribution of assets of the corporation. As such, equity is riskier than subordinated debt which, in turn, is riskier than senior debt. If prices are informative, a component of the price of each security should account for the institution's risk. There must be a common denominator that runs through the prices of senior, subordinated debt and equity assessing the state of riskness of the corporation. However, the information contained in prices is multiple and diverse, and the question becomes how to isolated the component of the price that provides information on idiosyncratic risk. This signal is implicit in the price and, consequently, unobservable to the investor and regulator. We need to device a mechanism for signal extraction.

Our approach for signal extraction is based on a linear decomposition of the return to equity and yields of subordinated and senior debt. Suppose that the return/yield of each security has two broad components: a systematic component and an idiosyncratic component. The systematic component is associated with market conditions such as the state of the stock market, the bond market, the Treasury yield curve, the state of the business cycle, etc. The idiosyncratic component is associated with the special characteristics of the security, such as embedded options, liquidity of the particular issue, etc, plus it will contain information about the state of riskness of the corporation. Our hypothesis is that within the idiosyncratic component of each security, the risk signal should be common to the three types of securities considered, and it will be captured by a single unobserved variable, which we call the "coincident indicator of bank risk". We proceed in two stages. In the first stage, because we have information on the state of the stock and bond markets, we linearly filter the systematic component in equity and debt. The filtered series for equity and debt are proxies for the idiosyncratic component of each security. In the second stage, the idiosyncratic component of each security is split between two unobservable components, one is common to all securities and represents the bank's risk signal, and the other is particular to each security and represents its individual characteristics. Hence, the bank signal, being implicit in the price, can be

considered as a residual signal that is uncorrelated with systematic components. The present approach answers directly to the opponents to proposals of subordinated debt as a 
bank monitoring device when they claim that subordinated yields, being contaminated by many non-credit related factors, are lacking clarity. The same criticism can be cast on any proposal that relies on secondary market prices of a single security. Our view is a global view in that, considering the secondary market prices of all securities that form the capital structure of the corporation, we aim to construct a multivariate signal with a higher signal-to-noise ratio than any other based on a single security. Formally, our model is the following.

Let $D s u b_{t}, D s e n_{t}$, and $R_{t}$ be the time series of changes in subordinated debt yields, senior debt yields, and return to equity, respectively; and let $f_{t}$ be a vector of factors. In the first stage of our approach, we remove the systematic component by running a regression as the following

$$
\left.\begin{array}{l}
\operatorname{Dsub}_{t}=\phi_{01}+\phi_{1}{ }^{\prime} f_{t}+\eta_{1 t} \\
\operatorname{Dsen}_{t}=\phi_{02}+\phi_{2}{ }^{\prime} f_{t}+\eta_{2 t} \\
R_{t}=\phi_{03}+\phi_{3}{ }^{\prime} f_{t}+\eta_{3 t}
\end{array}\right\}
$$

The factors that we consider are the stock market, the bond market and Treasury market. The state of the equity market is represented by the returns to the SP500 index. The state of the bond market is represented by the returns to the 10-year Treasury notes, and the 10-year AAA bank and financial bond index. More specific market conditions, i.e. liquidity concerns, that affect subordinated debt (rated $\mathrm{A}$ in the corporations that we consider below) and senior debt (rated $\mathrm{A}+$ ) are represented by two indexes, the 10-year A and $\mathrm{A}+$ financial firms bond indexes.

In the second stage, we retrieve the filtered series, which are the residuals of (1). Let $\eta_{1 t} \equiv D \operatorname{subf} f_{t}, \eta_{2 t} \equiv D \operatorname{senf}_{t}, \eta_{3 t} \equiv R f_{t}$ be the respective time series of changes in the filtered subordinated debt yields, senior debt yields and returns to equity. These series represent the idiosyncratic component for each security in which we hypothesize that there is a non-observable common denominator conveying the state of risk of the corporation. Our model consists of the following equations

$$
\left.\begin{array}{l}
\operatorname{Dsubf}_{t}=\beta_{01}+\beta_{1} S_{t}+u_{1 t} \\
\operatorname{Dsenf}_{t}=\beta_{02}+\beta_{2} S_{t}+u_{2 t} \\
R f_{t}=\beta_{03}+\beta_{3} S_{t}+u_{3 t}
\end{array}\right\}
$$


In equation (2), each series has two stochastic components, one is the unobserved risk signal $S_{t}$ that is common to the three series, and the other is an error component $u_{i t}$ $\{i=1,2,3\}$ that represents idiosyncrasies of each type of securities and measurement error. The risk signal enters into the set of equations (2) contemporaneously but with a different weight in each equation. A priori the risk signal may be dynamic and in equation (3) we allow for a general autoregressive structure. We also allow for autocorrelation in the idiosyncratic term $u_{i t}$ and in the system of equations (4) we write general autoregressive structures. The lag polynomials $\Phi(L), \Psi_{1}(L), \Psi_{2}(L), \Psi_{3}(L)$ are all of finite order. Since $S_{t}$ and $u_{i t}$ are both unobservable, for identification purposes, we need to assume that both are mutually uncorrelated at all leads and lags.

The main task is to retrieve the coincident indicator $S_{t}$. If the model (2) is correct, that is, if there is a common component to the three series, we should expect the estimates $\beta_{1}, \beta_{2}$, and $\beta_{3}$ be statistically significant with $\beta_{1}, \beta_{2}$ having opposite signs to that of $\beta_{3}$. This is because, when the corporation becomes riskier, we should expect debt yields to increase since investors will be selling the debt securities pushing their price down and, at the same time, the return to equity will go down since investors will be also selling the stock. This is the role that we should expect to be played by secondary market prices of debt and equity if there are truly informative about the fundamentals of the corporation. However one may claim that the same behavior will be triggered by systematic events such as a recession, where stocks fall out of favor and we observe a sell out with declines in stock prices that can bring a corporation to the brink of default. What would it be the role of our signal in this case? The return to equity of the corporation will react to the state of the market according to its historical load $\phi$ estimated in (1). If the fundamentals of the firm are not robust, it is expected that the drop in equity prices will be more severe than that corresponding to its historical behavior. This extra drop will be realized in the residual of the system (1). At the same time, bondholders evaluating the new state of the corporation will perceive the extra risk by dumping the bonds and raising the yield. Our signal $S_{t}$ in system (2) will indicate that there is a joint drop in returns and an increase in debt yields that do not correspond to historical norms sending an alert to regulators. The risk signal is an indicator of extraordinary circumstances but it will not detect the specific cause that has triggered the exceptional event.

It may be also argued that the risk signal may be filtering too much information because it does not capture the volatility of returns, which in turn can affect the likelihood of financial distress. This is a potential problem for which a more sophisticated model, which will include first and second moments, is needed. However, in an indirect way, the risk signal will take care of this problem. Since the signal is allowed to be autocorrelated, an increase of volatility, related to financial distress, will be picked up by the risk signal over time. How soon it will be picked up, it will depend on the degree and shape of the autocorrelation function of the signal. If there is high volatility, there will be large movements below and above the mean return. If the movements below the mean are severe enough and they are accompanied by large positive changes in the debt yields, the proposed risk signal will flush an alert. The trade-off faced by regulators is either to entertain a parsimonious model that provides fast valuable information or a more complicated model that may produce a marginal increase in information, which may be 
already available in other complementary signals. Our view is that the proposed signal is easy to implement and it should be understood as an alert mechanism that will complement other signals, some focusing on the volatility of the returns series.

\section{Implementation of the risk signal}

We implement the dynamic risk signal model, summarized in equations (1), (2), (3) and (4), for two banking institutions: Bank of America after its merger with Nations Bank in October 1, 1998, and Banker's Trust, involved in fraudulent derivatives trading for which federal racketeering charges were filed in Sept 1995. In the following sections, we provide a detailed implementation of the risk signal model for the Bank of America and a summarized version for Banker's Trust.

\subsection{Bank of America. Description of the data}

In the Fixed Investment Securities Database (FISD), we have searched for subordinated debt and senior debt issued by the Bank of America/Nations Bank Corporation. These two institutions merged on October 1, 1998. Our search aims to collect securities with similar financial characteristics but with different claims on the assets of the corporation. We have matched subordinated debt to senior debt and to Treasury notes. The three types of securities have a 10-year maturity and a semi-annual coupon frequency; they are noncallable and were issued around the same time. We have selected the following debentures: a subordinated debt issued on 1.29 .1998 with an annual coupon of $6.375 \%$; a senior debt issued on 3.24 .1998 with an annual coupon of $6.26 \%$; and a Treasury Note issued on 2.11 .1998 with an annual coupon of 5.5\%. The S\&P ratings of the subordinated debt is $\mathrm{A}$ and that of the senior debt is $\mathrm{A}+$.

We have retrieved the time series of the daily yields to maturity of these securities from Bloomberg. We analyze the average of the yield bid and ask quotes. In the upper panel of Table 1, we provide a descriptive summary of the yields to maturity for subordinated debt, senior debt and the Treasury Note for the period October 1, 1998 to July 27, 2001. The median yield of subordinated debt is 20 basis points above the median senior debt yield and 137 basis points above the Treasury notes. In the lower panels of Table 1, we show a summary of descriptive statistics of the debt yield changes, return to equity, and spreads to Treasury. The average yield change for subordinated debt, senior debt, Treasury notes, and return to equity is almost 0.0 . However, the standard deviation of return to equity is approximately 2.5 times larger than the standard deviation of the fixed income securities. The average subordinated debt spread to Treasury is about 130 basis points, with a maximum of 200 basis points at the end of the year 2000. Subordinated debt yield changes are highly correlated with changes in senior debt yields and Treasury yields, with correlations of 0.7 . However the correlation with returns to equity is practically zero. In Figure 1, we can observe the higher volatility of return to equity compared to that of subordinated and senior debt yield changes. The yield changes seem to be more volatile at the end of the sample, in the year 2001. 
Standard tests for unit root confirm that the debt yields and the equity prices are nonstationary, and they are not cointegrated. However, the changes in yields and return to equity are stationary ${ }^{9}$. Hence, the construction of a dynamic signal of institutional risk should rely on the analysis of the changes or movements in subordinated debt, senior debt and Treasury yields, and in the return to equity.

\subsection{Bank of America. Estimation of the risk signal}

The first stage of our methodology consists of estimating system (1) to obtain the time series filtered from market conditions. In Table 2, we present the results of regressing changes in subordinated debt yields, senior debt yields and return to equity on a variety of financial indexes, which capture the state of the equity and bond markets. The equity market is represented by the returns to the SP500 index (Rt_sp500). The state of the bond market is summarized by the movements in the yield of four types of securities. We consider the risk-free 10-year Treasury Notes (Dtre), and the 10-year AAA bank and financial bond index (Dbf10yaaa). The yield changes of these two types of securities are highly correlated with a coefficient of correlation of 0.87 . Since the subordinated debt and senior debt that we analyze are rated A and A+ respectively, we have included two indexes that represent market conditions affecting these two grades of securities, i.e. liquidity concerns. We consider the 10-year A and A+ financial firms bond indexes (Dfn10ya+, Dfn10ya).

Movements in the subordinated debt yield are correlated mainly with movements in the Treasury yields, and to a lower extent, with movements in the yields of the subordinated debt market. One percent increase in the Treasury yield changes translates into $0.72 \%$ in the subordinated debt yield changes. Movements in the senior debt yield have a similar sensitivity to movements in the Treasury yield. However, the senior debt seems to be more sensitive to the specific A+ bond market movements. The return to equity loads primarily in the market portfolio with a beta of 1.17. Overall, we can see that market conditions explain $32 \%$ of the variance of return to equity, $58 \%$ of the variance of subordinated debt yield changes, and $76 \%$ of the variance of senior debt yield movements. In other words, the riskier the security, the smaller proportion of its variance can be explained by the state of the markets; there is a larger idiosyncratic component in equity than in subordinated debt, and this one, in turn, has a larger idiosyncratic component than the senior debt. We extract the idiosyncratic component of the series by subtracting the effect of market conditions from the original series. The new filtered series are the residuals of the regressions reported in Table 2.

In the second stage, we proceed to extract the risk signal $S_{t}$ estimating equations (2), (3), and (4). We propose different specifications for the autoregressive structures of (3) and (4). Standard model selection procedures based on likelihood ratio tests and on the Akaike and Schwarz information criteria seem to indicate that the preferred specification for $S_{t}$ is an $\mathrm{AR}(1)$ process, for $u_{1 t}$ an $\mathrm{AR}(1)$, for $u_{2 t}$ an $\mathrm{AR}(2)$, and for $u_{3 t}$ an $\operatorname{AR}(0)$.

\footnotetext{
${ }^{9}$ Results of unit root and cointegration tests can be provided upon request.
} 
In Table 3, we report the maximum likelihood estimates of the parameters of model. In the upper panel, we considered the filtered series from regression (3) presented in Table 2 , and in the lower panel, the filtered series from regression (2) in the same table. The estimation results of both panels are virtually identical. The subordinated debt yields and the senior debt yields load positively in the risk signal and the returns to equity load negatively in the signal. This means that when the signal is positive, there is an increase in yield changes and a decrease in returns as expected when the risk profile of the corporation increases. The loadings for the yields, $\beta_{1}$ and $\beta_{2}$, are statistically very significant with the same p-value of $0.01 \%$; the loading for the returns $\beta_{3}$ is marginally significant with a $\mathrm{p}$-value of $17 \%$. The magnitude of the loadings is very similar across securities but subordinated debt yields and returns are the most sensitive to changes in the risk signal. The idiosyncratic component of the filtered yield series is negatively correlated as it is indicated by the negative values of $\psi_{i j}$ 's. The risk signal has zero mean, a standard deviation of one, and is positively autocorrelated; it follows an AR(1) with a high persistence parameter of 0.84 . Significant departures from zero are the signals that regulators and investors are most interested in because they indicate extraordinary changes in debt yields and return to equity which are not driven by general market conditions. The risk signal has a correlation of 0.45 with the filtered senior debt yield changes, a correlation of 0.33 with those of subordinated debt, and -0.10 with filtered returns to equity.

In Figure 2, we present the estimated time series risk signal $S_{t \mid t}$ together with a 95\% confidence band. The shaded areas represent the signals that are statistically different from zero and larger (in magnitude) than two standard deviations. These represent extraordinary events. A positive signal indicates an increase in risk, and a negative signal a decrease in risk. We observe that the market perceived an increase in risk in Bank of America just after the merger with Nations Bank in October 1998 but it was eased by the subsequent decrease in November and December of 1998. The next two events of uprising risk are in January 2000 and November 2000. In January 2000, Bank of America disclosed losses in its bond and interest-rate swaps portfolios, which grew to $\$ 5.3$ billions in the fourth quarter of 1999 from $\$ 3.7$ billions in the third quarter. In November 2000, Bank of America wrote off $\$ 1.1$ billion for bad loans. This was also a period of high uncertainty generated by speculation on the tenure of CEO Hugh McColl.

In Figure 3, we compare the time events provided by the risk signal with the behavior of the equity price and the subordinated debt and senior debt spreads to treasury. A positive risk signal is associated with a decline in equity prices jointly with a substantial increase in both spreads. Conversely, a negative risk signal is associated with an increase in equity prices and lower spreads. It is interesting to note that from February to October 2000 the subordinated debt spread and senior spread were steadily rising but the equity price was relatively stable, thus the risk signal was basically zero. It took a substantial drop in the equity price to its lowest level between $10 / 1999-7 / 2001$ ( $\$ 40$ per share) coupled with a substantial increase in the senior debt spread to set off the risk signal, which jumped about four standard deviations. Another interesting event is April 2001. The senior debt spread rose to its highest level in the analyzed period but the risk signal indicated a decrease in risk. This was due to the rising equity prices and lower subordinated debt 
spreads. In summary, the risk signal exploits the joint behavior of fixed income securities and equity.

\subsection{Bank of America. Forecasting the risk signal: a leading indicator}

The coincident indicator built in the previous section alerts investors and regulators about concurrent risk changes, that is, risk that is developing on the spot. It would be desirable for the regulators to forecast when risk will develop. Hence, the question is: is there any leading indicator that can anticipate alert movements in the risk signal? Subordinated debt proposals recommend the follow up of subordinated debt spreads to monitor the risk of the corporation. In this section, we claim that this follow up is not sufficient and it needs to be complemented with information contained in other securities issued by the institution. We show that the subordinated debt spread is a poor indicator of risk changes and we propose the construction of a leading indicator for the risk signal based on the subordinated debt and senior debt spreads and equity returns.

In Table 4, we collect preliminary evidence on the lead-lag relation between the risk signal and subordinated debt and senior debt spread changes and equity returns. In the upper panel, we report the cross-correlation between the lagged risk signal and concurrent changes in spread and equity returns. These correlations are statistically zero, as expected, since the risk signal is not designed to forecast equity returns or spreads. However, the cross-correlation between the future risk signal and concurrent changes in spread and equity returns is more interesting because it has information on the ability of equity returns and spreads to forecast the risk signal. In the lower panel of Table 4, we observe that for equity returns, this cross-correlation is negative (about -0.10 ), the lower the returns, the larger the signal. For changes in the spreads, the cross-correlation is positive (about 0.30 one-period ahead), the larger the changes in the spread, the larger the risk signal will be. Thus, changes in spreads and equity prices seem to have power to forecast the movements in the risk signal.

To formalize the leading behavior of spreads and equity returns, we construct a VAR system with four variables: the risk signal, returns to equity, subordinated debt spread changes, and senior debt spread changes. Standard statistical procedures indicate that the optimal length of the VAR is two lags. We report the estimation results for the equation of the risk signal, which is the following (t-statistics in parenthesis)

$$
\begin{aligned}
& S_{t}=-0.01-0.04 R_{t-1}-0.01 R_{t-2}+0.03 \text { DspSub }_{t-1}+0.00 \mathrm{DspSub}_{t-2}+ \\
& \quad \begin{array}{l}
(-0.3) \quad(-3.9) \quad(-0.8) \\
\quad+0.05 \text { DspSen }_{t-1}+0.01 \mathrm{DspSen}_{t-2}+0.51 S_{t-1}+0.26 S_{t-2}+\varepsilon_{t}
\end{array} \\
& \quad(2.3) \quad(0.7) \\
& \text { Adj.R } \text { - squared }=0.69
\end{aligned}
$$

where $R_{t}$ is the return to equity, $D s p S u b_{t}$ is the change in the subordinated debt spread to treasury, and $D_{s p S e n}$ is the change in the senior debt spread to treasury. Grangercausality tests indicate that returns to equity, subordinated debt spread changes, and 
senior debt spread changes have a strong forecasting ability for the risk signal (they reject the null hypothesis of non-Granger causality with p-values of $0.0004,0.02$, and 0.05 respectively). In Figure 4, we show the VAR impulse response function corresponding to the risk signal. These functions confirm the leading behavior of spread changes and equity returns documented in Table 4 . The three graphs in the upper panel of Figure 4 confirm that the risk signal does not forecast either returns or spreads. However, in the lower panel, we observe that the risk signal seems to respond strongly to changes in the senior debt spreads and to changes in subordinated debt spreads, and to a lesser extent to changes in equity prices. We find that $52 \%$ of the variance of the risk signal is due to senior debt spread changes, $35 \%$ is due to subordinated debt spread changes, $7 \%$ is due to equity returns, and the remaining $6 \%$ is due to its own innovations. Finally, the leading indicator is constructed as the one-day-ahead forecast of the risk signal using equation (6). We find that this leading indicator and the actual value of the risk signal have a strong correlation of 0.83 .

\subsection{The risk signal for Banker's Trust}

We apply the same methodology to Banker's Trust, which went through several episodes of financial distress. Banker's Trust was involved in several well-publicized scandals involving derivatives trading, beginning in 1993 and leading to the filing of federal racketeering charges against the institution in September 1995. In the summer and fall of 1998, Bankers's Trust suffered substantial losses from investments in emerging markets as a result of the ongoing emerging markets currency crisis, which led in November 1998 to the announcement of a takeover by the Deutsche Bank.

From FISD and Bloomberg databases, we collect data on yields to maturity of subordinated debt and senior debt issued by Banker's Trust and Government Treasury Notes with very similar financial characteristics. The three types of securities have a 10year maturity. The subordinated debt was issued on 4.19.1995 with a semiannual coupon of $8.25 \%$ and was rated $\mathrm{A}$; the senior debt was issued on 8.16 .1995 with a semiannual coupon of 7.625\% and A+ rating; and the Treasury Note was issued on 2.15.1995 with a semiannual coupon of $7.5 \%$. The period of analysis goes from 8.16.1995 to 6.3.1999, when the merger with the Deutsche Bank took place.

In Table 5, we report the estimation results and the extraction of the risk signal. In the upper panel, we extract the market components of the yield changes and equity returns. The market explains $40-50 \%$ of the changes in the yields of the subordinated and senior debts and $26 \%$ of the variance of the equity returns. The market factors affecting the subordinated and senior debts are the treasury market for both debts and the state of the market corresponding to the $\mathrm{A}$ and $\mathrm{A}+$ rated bonds. The equity return has a market beta of 0.93 and it is also affected by the state of the bond market. In the lower panel of Table 6 , we proceed to the extraction of the risk signal. Once the yield changes and return are filtered from market conditions, we search for a common signal across the three securities. The preferred econometric specification is very similar to that of the Bank of America with the exception that the signal $S_{t}$ in the present case does not seem to behave as an $\mathrm{AR}(1)$ process; however the same order in the autoregressive structures remain for 
$u_{1 t} \mathrm{AR}(1)$, for $u_{2 t}$ an $\mathrm{AR}(2)$, and for $u_{3 t}$ an $\mathrm{AR}(0)$. The risk signal in the Banker's Trust case is stronger than in the case of the Bank of America. The loadings for the debt yields and the equity return, $\beta_{1}, \beta_{2}$ and $\beta_{3}$ have the right signs and are statistically very significant with p-values of zero. The magnitude of the loading in the subordinated debt yields is the largest indicating that this type of security is the most sensitive to changes in the risk signal.

In Figure 5, we plot the risk signal $S_{t}$. We observe that there are two main periods of extreme stress. The first one is October/November 1995 after the filing of federal racketeering charges against Banker's Trust. The second one is the period surrounding the emerging markets currency crisis of 1998. The signal peaks in October 1998 and it eases off in November of 1998 after the announcement of the merger with the Deutsche Bank.

\section{Conclusions}

Our main objective has been the development of a dynamic risk signal that is valuable to the regulator to monitor and assess in real time the risk profile of a financial institution. The proposed signal is an additional and complementary tool that bank supervisors can add to their tool kit for monitoring institutional risk. We have proposed a multivariate dynamic signal that combines fluctuations in equity prices, subordinated debt, and senior debt, issued by the institution. The proposed signal has to be dynamic because the regulator needs to take corrective actions in a timely fashion. Numerous cross-sectional studies of subordinated debt find a positive correlation between measures of risk and subordinated yield spreads. These cross-sectional studies are important to support the implementation of policy proposals but, by their nature, they are not suitable to assess risk in real time. The proposed signal is multivariate because we presume that bondholders and stockholders may have a common interest in the long run viability of the institution, contrary to the wide spread moral hazard arguments that support the view that the incentives of bondholders and stockholders are not aligned, disqualifying equity prices as informative signals.

We have constructed a coincident indicator of risk that is based on the value of a joint claim. The common feature of the three most representative liabilities of the corporation - equity, subordinated debt, and senior debt - is that they are claims, although with different priority, on the same assets of the institution and their pricing must have a common component that accounts for institutional idiosyncratic risk. Our risk signal extracts this common component. The characteristics of the proposed risk signal are: (1) it is stochastic since it is based on a time series model of yield changes and equity returns; (2) it is non-observable; we extract it from yield fluctuations and equity returns; (3) it monitors idiosyncratic risk of the corporation because subordinated debt and senior debt yields as well as equity returns are filtered from systematic risk or market conditions; and (4) it is predictable to a larger degree because it is possible to construct a leading indicator based mostly on subordinated debt and senior debt spreads to Treasury and, to a lesser extent, on equity returns. 
To apply our methodology, we have collected data on daily yields and equity prices for two banking institutions: the Bank of America from October 1, 1998, when it merged with Nations Bank, up to July 27, 2001; and Banker's Trust from August 16, 1995 to June 3, 1999, when the merger with the Deutsche Bank took place. We have offered a detailed analysis of the implementation of the risk signal based on the data of the Bank of America, for which the results are summarized as follows. In a first stage we have removed the systematic component or market conditions from the fluctuations in yields and equity returns. It is interesting to note that the riskier the security, the smaller proportion of its variance can be explained by market forces. Market conditions explain $32 \%$ of the variance of equity return, and $58 \%$ and $76 \%$ of the variance of subordinated yield changes and senior debt changes, respectively. Our institutional risk signal is a coincident indicator that accounts for the common information that remains in yield changes and equity returns after market conditions have been taken into account. The estimated signal has mean zero and is positively autocorrelated. A positive signal indicates an increase in the risk profile of the corporation because it is associated with an increase in yield fluctuations and with a decrease in equity returns. The signal points out to two events of uprising risk, one in January 2000 and another in November 2000, where there was a substantial increase in the subordinated and senior debt spreads to Treasury jointly with a substantial decline in equity prices. In January 2000, Bank of America disclosed losses in its bond and interest-rate swaps portfolios, which grew to $\$ 5.3$ billions in the fourth quarter of 1999 from $\$ 3.7$ billion in the third quarter. In November 2000, Bank of America wrote off $\$ 1.1$ billion for bad loans. This was also a period of high uncertainty generated by speculation on the tenure of CEO Hugh McColl. For the case of the Banker's Trust, market conditions explain between 40 and $50 \%$ of the variance of subordinated yield changes and senior debt changes, and $26 \%$ of the variance of the equity returns. The risk signal for Banker's Trust points to the period when the racketeering charges against the bank were filed, and to the period surrounding the emerging markets currency crisis of 1998.

We have also shown that the follow up of subordinated debt spreads, as policy proposals recommend, is a partial indicator of risk changes in the corporation. For the case of Bank of America, we have constructed a leading indicator of the risk signal that is based on subordinated and senior debt spreads to Treasury and on equity returns. Based on a VAR system, we have found that, interestingly enough, $52 \%$ of the variance of the risk signal is explained by senior debt spread fluctuations, $35 \%$ by subordinated debt spread fluctuations, $7 \%$ by equity returns, and the remaining $6 \%$ by its own innovations.

It would be desirable to implement the signal for additional institutions that have been under financial distress in the recent times. Unfortunately, there were few cases in the 1990's. We found that Bank One would be an interesting case because in 1999 and 2000 this institution went through a period of considerable financial stress. However, the time series data on subordinated debt yields issued by the bank was very poor, lacking information for long periods of time. The substantial number of missing data points would have required making many judgment calls, and consequently, would have cast doubts on the results of our analysis. 
In summary, while we find support for the view, as espoused by Flannery (1998) and others, that the prices of various liabilities issued by a financial intermediary do respond to changes in institutional risk, we also find that no single asset price provides sufficient information to serve as a single signal of solvency risk. Indirect market discipline can, however, be achieved by monitoring not only the yields of subordinated debt but also by monitoring secondary market prices of senior debt and equity. Regulators and investors should consider all market information that is available because each type of security contains non-redundant information about the risk profile of the banking corporation. 


\section{References}

Aharoney, J. and I. Swary (1996) "Additional Evidence on the Information-based Contagion Effects of Bank Failures,” Journal of Business 56(3), 305-22.

Asness, C. and M. Smirlock (1991) "A Note on REIT Bankruptcy and Intra-industry Information Transfers: An Empirical Analysis," Journal of Banking and Finance 15(2), 1171-82.

Avery, R., T. Belton and M. Goldberg (1988), "Market Discipline in Regulating Bank Risk: New Evidence from Capital Markets," Journal of Money, Credit and Banking 20(4), November, 597-610.

Baer, H. and E. Brewer (1986) "Uninsured Deposits as a Source of Market Discipline: Some New Evidence," Federal Reserve Bank of Chicago Economic Perspectives, September/October, 23-31.

Berger, A. (1991) "Market Discipline in Banking," Proceedings of the $27^{\text {th }}$ Annual Federal Reserve Bank of Chicago Conference on Bank Structure and Competition, May.

Bliss, R.R. (2000), "Market Discipline and Subordinated Debt: A Review of Some Salient Issues", Economic Perspectives, Federal Reserve Bank of Chicago.

Cargill, T. (1989) "CAMEL Ratings and the CD Market," Journal of Financial Services Research, 3, 347-58.

Dewatripont, M. and J. Tirole (1994) The Prudential Regulation of Banks. Cambridge: MIT Press.

DeYoung, R., M. Flannery, W. Lang and S. Sorescu (2001), "The Informational Advantage of Specialized Monitors: The Case of Bank Examiners," Journal of Money, Credit and Banking, 33.

Edwards, A., L. Harris, and M. Piwowar (2004), “Corporate Bond Market Transparency and Transaction Costs",

http://papers.ssrn.com/sol3/papers.cfm?abstract_id=593823.

Ellis, D and M. Flannery (1992) "Does the Debt Market Assess Large Banks' Risks?" Journal of Monetary Economics 27, December, 481-502.

Evanoff, D. and L. Wall (2000) "The Role of Subordinated Debt in Bank Safety and Soundness Regulation," Proceedings of the $36^{\text {th }}$ Annual Federal Reserve Bank of Chicago Conference on Bank Structure and Competition, May. 
Federal Reserve Board and U.S. Department of the Treasury (2000), "The Feasibility and Desirability of Mandatory Subordinated Debt", December.

Flannery, M. (1998) "Using Market Information in Prudential Bank Supervision: A Review of the U.S. Empirical Evidence," Journal of Money, Credit and Banking 30(3), August (Part I), 273-305.

Flannery, M. and S. Sorescu (1996) "Evidence of Bank Market Discipline in Subordinated Debenture Yields: 1983-1991," Journal of Finance 51(4), September, 1347-77.

Gilbert, R. A. (1990) "Market Discipline of Bank Risk: Theory and Evidence," Quarterly Review of the Federal Reserve Bank of St Louis, January/February, 3-18.

Gorton, G. and A. Santomero (1990), "Market Discipline and Bank Subordinated Debt," Journal of Money, Credit and Banking, 22(1), February, 119-128.

Hancock, D. and M. Kwast (2001) "Using Subordinated Debt to Monitor Bank Holding Companies: Is It Feasible?", Journal of Financial Services Research 20, 147-187.

Hannan, T. and G. Hanweck (1988) "Bank Insolvency Risk and the Market for Large Certificates of Deposit," Journal of Money, Credit and Banking 20, May, 203-12.

Haubrich, J. G. (1998), “Subordinated Debt: Tough Love for Banks?” Federal Reserve Bank of Cleveland, Economic Commentary.

Hughes, J., W. Lang, C. Moon and M. Pagano (1999) "Measuring the Efficiency of Capital Allocation in Commercial Banking," Proceedings of the $35^{\text {th }}$ Annual Federal Reserve Bank of Chicago Conference on Bank Structure and Competition, May, 407-429.

James, C. "Heterogeneous Creditors and the Market Value of Bank LDC Loan Portfolios," Journal of Monetary Economics 22, 395-422.

Keeley, M. (1990) "Deposit Insurance, Risk and Market Power in Banking," American Economic Review 8, 1183-1200.

Lang, W. and D. Robertson (2002) "Analysis of Proposals for a Minimum Subordinated Debt Requirement," Journal of Economics and Business, 54(1), 115-136.

Levonian, M. (2001) "Subordinated Debt and the Quality of Market Discipline in Banking”, Working Paper, Federal Reserve Bank of San Francisco.

Merton, R. (1974) "On the Pricing of Corporate Debt: The Risk Structure of Interest Rates," Journal of Finance, May, 449-70. 
Merton, R. (1977) "An Analytic Derivation of the Cost of Deposit Insurance and Loan Guarantees," Journal of Banking and Finance 1, June, 3-11.

Morgan, D. and K. Stiroh (1999) "Bond Market Discipline of Banks: Is the Market Tough Enough?" Proceedings of the $36^{\text {th }}$ Annual Federal Reserve Bank of Chicago Conference on Bank Structure and Competition, May.

Repullo, R. (2000) "Who Should Act as Lender of Last Resort? An Incomplete Contracts Model," Journal of Money, Credit and Banking 32(3), August, Part 2, 580-605.

Repullo, R. and J. Suarez (1998) "Monitoring, Liquidation and Security Design," Review of Financial Studies 11(1), Spring, 163-87.

Wall, L. (1989) “A Plan for Reducing Future Deposit Insurance Losses: Puttable Subordinated Debt," Federal Reserve Bank of Atlanta Economic Review 74(4), 217. 
Table 1

Bank of America/Nations Bank

Descriptive Statistics

Yield to Maturity

Subordinated Debt, Senior Debt, and Treasury Notes with similar characteristics.

Securities issued in 1998. Sample: Oct 1, 1998-July 27, 2001

\begin{tabular}{|l|c|c|c|}
\hline & YSUB_98 & YSEN_98 & YTRE_98 \\
\hline \hline Mean & 6.984 & 6.956 & 5.656 \\
\hline Median & 7.172 & 6.974 & 5.796 \\
\hline Maximum & 8.215 & 8.237 & 6.823 \\
\hline Minimum & 5.497 & 5.420 & 4.148 \\
\hline Std. Dev. & 0.647 & 0.584 & 0.637 \\
\hline Skewness & -0.341 & -0.126 & -0.080 \\
\hline Kurtosis & 2.090 & 2.306 & 1.798 \\
\hline
\end{tabular}

Yield to Maturity Changes (subordinated debt, senior debt, and treasury notes), Return to Equity, and Spreads to Treasury

Descriptive Statistics

\begin{tabular}{|l|c|c|c|c|c|c|}
\hline & DSUB_98 & DSEN_98 & DTRE_98 & RETEQ & $\begin{array}{c}\text { Spread } \\
\text { (sub to tres.) }\end{array}$ & $\begin{array}{c}\text { Spread } \\
\text { (senior to tres.) }\end{array}$ \\
\hline \hline Mean & 0.012 & 0.022 & 0.017 & 0.023 & 1.322 & 1.301 \\
\hline Median & 0.000 & -0.027 & -0.020 & 0.000 & 1.286 & 1.338 \\
\hline Maximum & 9.035 & 4.327 & 4.839 & 8.217 & 2.025 & 1.953 \\
\hline Minimum & -4.499 & -3.725 & -4.222 & -11.532 & 0.791 & 0.735 \\
\hline Std. Dev. & 1.063 & 1.030 & 1.134 & 2.650 & 0.306 & 0.282 \\
\hline Skewness & 0.800 & 0.330 & 0.374 & 0.079 & 0.324 & 0.015 \\
\hline Kurtosis & 11.683 & 4.376 & 4.507 & 3.799 & 1.981 & 1.887 \\
\hline
\end{tabular}

Correlation Matrix

\begin{tabular}{|c|c|c|c|c|c|c|}
\hline & DSUB_98 & DSEN_98 & DTRE_98 & RETEQ & SP_SUB & SP_SEN \\
\hline \hline DSUB_98 & 1.000 & 0.691 & 0.764 & 0.013 & -0.018 & -0.065 \\
\hline DSEN1_98 & 0.691 & 1.000 & 0.863 & 0.052 & -0.047 & -0.018 \\
\hline DTRE1_98 & 0.764 & 0.863 & 1.000 & 0.060 & -0.077 & -0.054 \\
\hline RETEQ & 0.013 & 0.052 & 0.060 & 1.000 & 0.043 & 0.066 \\
\hline SP_SUB & -0.018 & -0.047 & -0.077 & 0.043 & 1.000 & 0.858 \\
\hline SP_SEN & -0.065 & -0.018 & -0.054 & 0.066 & 0.858 & 1.000 \\
\hline
\end{tabular}


Table 2

Bank of America/Nations Bank

Systematic Risk in Subordinated Debt, Senior Debt, and Equity

\begin{tabular}{|c||c|c|c||c|c|c||c|c|c|}
\hline $\begin{array}{c}\text { Dependent } \\
\text { variable }\end{array}$ & \multicolumn{3}{|c||}{ Dsub } & \multicolumn{3}{c||}{ Dsen } & \multicolumn{3}{c|}{ Rt } \\
\hline \hline Regressors & $(1)$ & $(2)$ & $(3)$ & $(1)$ & $(2)$ & $(3)$ & $(1)$ & $(2)$ & $(3)$ \\
\hline Rt_sp500 & -0.02 & & & 0.02 & & & 1.18 & 1.17 & 1.17 \\
& $(-0.88)$ & & & $(1.41)$ & & & $(16.51)$ & $(16.83)$ & $(17.16)$ \\
\hline Dtre & 0.65 & 0.64 & 0.72 & 0.48 & 0.55 & 0.78 & -0.33 & & \\
& $(11.33)$ & $(14.61)$ & $(27.66)$ & $(6.46)$ & $(10.02)$ & $(46.2)$ & $(-1.62)$ & & \\
\hline Dbf10yaaa & -0.04 & & & 0.11 & & & 0.33 & 0.09 & \\
& $(-0.58)$ & & & $(2.02)$ & & & $(1.69)$ & $(0.90)$ & \\
\hline Dfn10ya+ & 0.05 & & & 0.20 & 0.33 & & 0.07 & & \\
& $(0.65)$ & & & $(2.86)$ & $(4.90)$ & & $(0.23)$ & & \\
\hline Dfn10ya & 0.09 & 0.11 & & 0.09 & & & 0.04 & & \\
& $(1.41)$ & $(1.83)$ & & $(1.26)$ & & & $(0.15)$ & & \\
\hline Adj-R & 0.58 & 0.58 & 0.58 & 0.76 & 0.76 & 0.74 & 0.32 & 0.32 & 0.32 \\
squared & & & & & & & & & \\
\hline
\end{tabular}

Dsub: change in the yield to maturity of 10-year subordinated debt.

Dsen: change in the yield to maturity of 10-year senior debt.

Rt: return to equity.

Rt_sp500 : return to the SP500 index.

Dtre: change in the yield to maturity of 10-year Treasury Notes.

Dbf10yaaa: change in the yield to maturity of bank and financial firms 10-year AAA bond index.

Dfn10ya+: change in the yield to maturity of financial firms 10-year A+ bond index. Dfn10ya: change in the yield to maturity of financial firms 10-year A bond index.

Robust t-statistics in parenthesis based on the Newey-West standard errors. 
Table 3

Bank of America/Nations Bank

Risk Signal Model

\begin{tabular}{|c|c|c|c|}
\hline & Dsub_f1 & Dsen_f1 & Rt_f1 \\
\hline$\beta_{1}$ & $0.08(0.02)$ & & \\
\hline$\beta_{2}$ & & $0.07(0.02)$ & $-0.08(0.05)$ \\
\hline$\beta_{3}$ & & & \\
\hline$\psi_{11}$ & $-0.26(0.02)$ & & \\
\hline$\psi_{21}$ & & $-0.35(0.05)$ & $1.56(0.04)$ \\
\hline$\psi_{22}$ & $-0.87(0.03)$ & $-1.50(0.05)$ & \\
\hline $\log \sigma^{2}{ }_{i}$ & \multicolumn{3}{|c|}{$S_{t}=0.84 S_{t-1}+\hat{v}_{t}$} \\
& $(0.05)$ & \\
\hline \multicolumn{4}{|c|}{$\log \ell=-2893.54$} \\
\hline
\end{tabular}

Asymptotic standard errors are in parenthesis.

Dsub_f1, Dsen_f1, Rt_f1 are the filtered series (residuals) from regression (3) in Table 2.

\begin{tabular}{|c|c|c|c|}
\hline & Dsub_f2 & Dsen_f2 & Rt_f1 \\
\hline$\beta_{1}$ & $0.07(0.02)$ & & \\
\hline$\beta_{2}$ & & $0.06(0.02)$ & $-0.09(0.06)$ \\
\hline$\beta_{3}$ & & & \\
\hline$\psi_{11}$ & $-0.26(0.02)$ & & \\
\hline$\psi_{21}$ & & $-0.33(0.05)$ & $1.56(0.04)$ \\
\hline$\psi_{22}$ & $-0.86(0.03)$ & $-1.53(0.05)$ & \\
\hline $\log \sigma^{2}{ }_{i}$ & \multicolumn{2}{|c|}{$S_{t}=0.82 S_{t-1}+\hat{v}_{t}$} \\
& $(0.07)$ \\
& $\log \ell=-2873.63$ \\
\hline
\end{tabular}

Asymptotic standard errors are in parenthesis

Dsub_f2, Dsen_f2 are the filtered series (residuals) from regression (2) in Table 2. 
Table 4

Bank of America/Nations Bank

\section{Lead and Lag Relation between the Risk Signal and Changes in Spread and Equity}

\begin{tabular}{|c|c|c|c|c|}
\hline & $i$ & $\operatorname{Corr}\left(R_{t}, S_{t+i}\right)$ & $\operatorname{Corr}\left(\operatorname{DspSub}_{t}, S_{t+i}\right)$ & $\operatorname{Corr}\left(\operatorname{DspSen}_{t}, S_{t+i}\right)$ \\
\hline \multirow[t]{11}{*}{ lag } & -10 & 0.10 & -0.02 & 0.02 \\
\hline & -9 & 0.06 & 0.01 & 0.02 \\
\hline & -8 & 0.00 & 0.01 & 0.04 \\
\hline & -7 & 0.01 & 0.02 & 0.03 \\
\hline & -6 & 0.02 & 0.00 & 0.05 \\
\hline & -5 & 0.02 & -0.03 & 0.05 \\
\hline & -4 & -0.01 & 0.00 & 0.06 \\
\hline & -3 & 0.02 & 0.04 & 0.09 \\
\hline & -2 & 0.02 & 0.04 & 0.09 \\
\hline & -1 & 0.04 & 0.00 & -0.03 \\
\hline & 0 & -0.04 & 0.31 & 0.41 \\
\hline \multirow[t]{10}{*}{ lead } & 1 & -0.10 & 0.28 & 0.34 \\
\hline & 2 & -0.09 & 0.21 & 0.27 \\
\hline & 3 & -0.08 & 0.20 & 0.19 \\
\hline & 4 & -0.09 & 0.17 & 0.18 \\
\hline & 5 & -0.13 & 0.14 & 0.13 \\
\hline & 6 & -0.10 & 0.10 & 0.12 \\
\hline & 7 & -0.10 & 0.08 & 0.08 \\
\hline & 8 & -0.06 & 0.06 & 0.09 \\
\hline & 9 & -0.08 & 0.07 & 0.07 \\
\hline & 10 & -0.06 & 0.07 & 0.07 \\
\hline
\end{tabular}

$\operatorname{Corr}\left(R_{t}, S_{t+i}\right)$ : correlation between the risk signal and return to equity.

$\operatorname{Corr}\left(\operatorname{DspSub}_{t}, S_{t+i}\right)$ : correlation between the risk signal and changes in the subordinated debt spread to treasury.

$\operatorname{Corr}\left(\operatorname{DspSen}_{t}, S_{t+i}\right)$ : correlation between the risk signal and changes in the senior debt spread to treasury. 
Table 5

Banker's Trust

Systematic Risk in Subordinated Debt, Senior Debt, and Equity

\begin{tabular}{|c||c|c||c|c||c|c|}
\hline $\begin{array}{c}\text { Dependent } \\
\text { variable }\end{array}$ & \multicolumn{2}{|c||}{ Dsub } & \multicolumn{2}{c|}{ Dsen } & \multicolumn{2}{c|}{ Rt } \\
\hline \hline Regressors & $(1)$ & $(2)$ & $(1)$ & $(2)$ & $(1)$ & $(2)$ \\
\hline Rt_sp500 & 0.02 & & 0.02 & & 0.92 & 0.93 \\
& $(0.72)$ & & $(0.70)$ & & $(13.55)$ & $(13.58)$ \\
\hline Dtre & 0.32 & 0.39 & 0.34 & 0.38 & 0.01 & \\
& $(2.40)$ & $(3.57)$ & $(2.38)$ & $(2.48)$ & $(0.06)$ & \\
\hline Dbf10yaaa & 0.11 & & -0.03 & & 0.42 & 0.47 \\
& $(0.79)$ & & $(-.30)$ & & $(2.29)$ & $(2.86)$ \\
\hline Dfn10ya+ & 0.22 & & 0.32 & 0.52 & 0.26 & \\
& $(1.12)$ & & $(1.28)$ & $(2.97)$ & $(0.87)$ & \\
\hline Dfn10ya & 0.25 & 0.49 & 0.29 & & -0.73 & -0.52 \\
& $(1.94)$ & $(4.09)$ & $(2.05)$ & & $(-2.67)$ & $(-2.79)$ \\
\hline $\begin{array}{c}\text { Adj-R } \\
\text { squared }\end{array}$ & 0.49 & 0.48 & 0.41 & 0.41 & 0.26 & 0.26 \\
\hline
\end{tabular}

Dsub: change in the yield to maturity of 10 -year subordinated debt.

Dsen: change in the yield to maturity of 10 -year senior debt.

Rt: return to equity.

Rt_sp500 : return to the SP500 index.

Dtre: change in the yield to maturity of 10-year Treasury Notes.

Dbf10yaaa: change in the yield to maturity of bank and financial firms 10-year AAA bond index.

Dfn10ya+: change in the yield to maturity of financial firms 10-year A+ bond index.

Dfn10ya: change in the yield to maturity of financial firms 10-year A bond index.

Robust t-statistics in parenthesis based on the Newey-West standard errors.

\section{Risk Signal Model}

\begin{tabular}{|c|c|c|c|}
\hline & Dsub_f2 & Dsen_f2 & Rt_f2 \\
\hline$\beta_{1}$ & $0.84(0.006)$ & & \\
\hline$\beta_{2}$ & & $0.53(0.006)$ & $-0.34(0.05)$ \\
\hline$\beta_{3}$ & & & \\
\hline$\psi_{11}$ & $-0.85(0.04)$ & & $0.27(0.01)$ \\
\hline$\psi_{21}$ & & $-0.27(0.01)$ & $0.95(0.02)$ \\
\hline$\psi_{22}$ & $-4.34(0.40)$ & $-0.31(0.02)$ & \\
\hline $\log \sigma^{2}{ }_{i}$ & \multicolumn{2}{|c|}{$S_{t}=-0.01 S_{t-1}+\hat{v}_{t}$} \\
\hline \multicolumn{4}{|c|}{$\log \ell=-4403.15$} \\
\hline
\end{tabular}

Asymptotic standard errors are in parenthesis.

Dsub_f2, Dsen_f2, Rt_f2 are the filtered series (residuals) from regression (2) in upper table. 
Figure 1

Bank of America/Nations Bank

Subordinated Debt and Senior Debt Yield Changes and Return to Equity
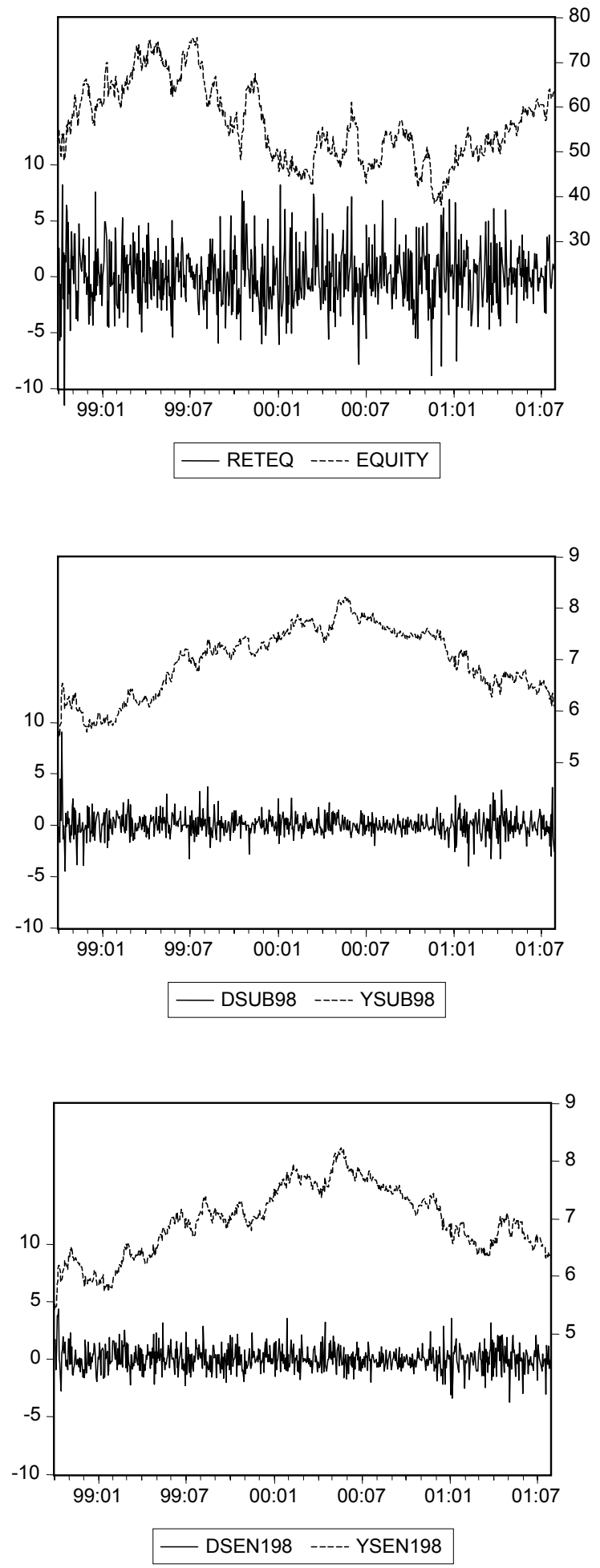
Figure 2

Bank of America/Nations Bank

Risk Signal

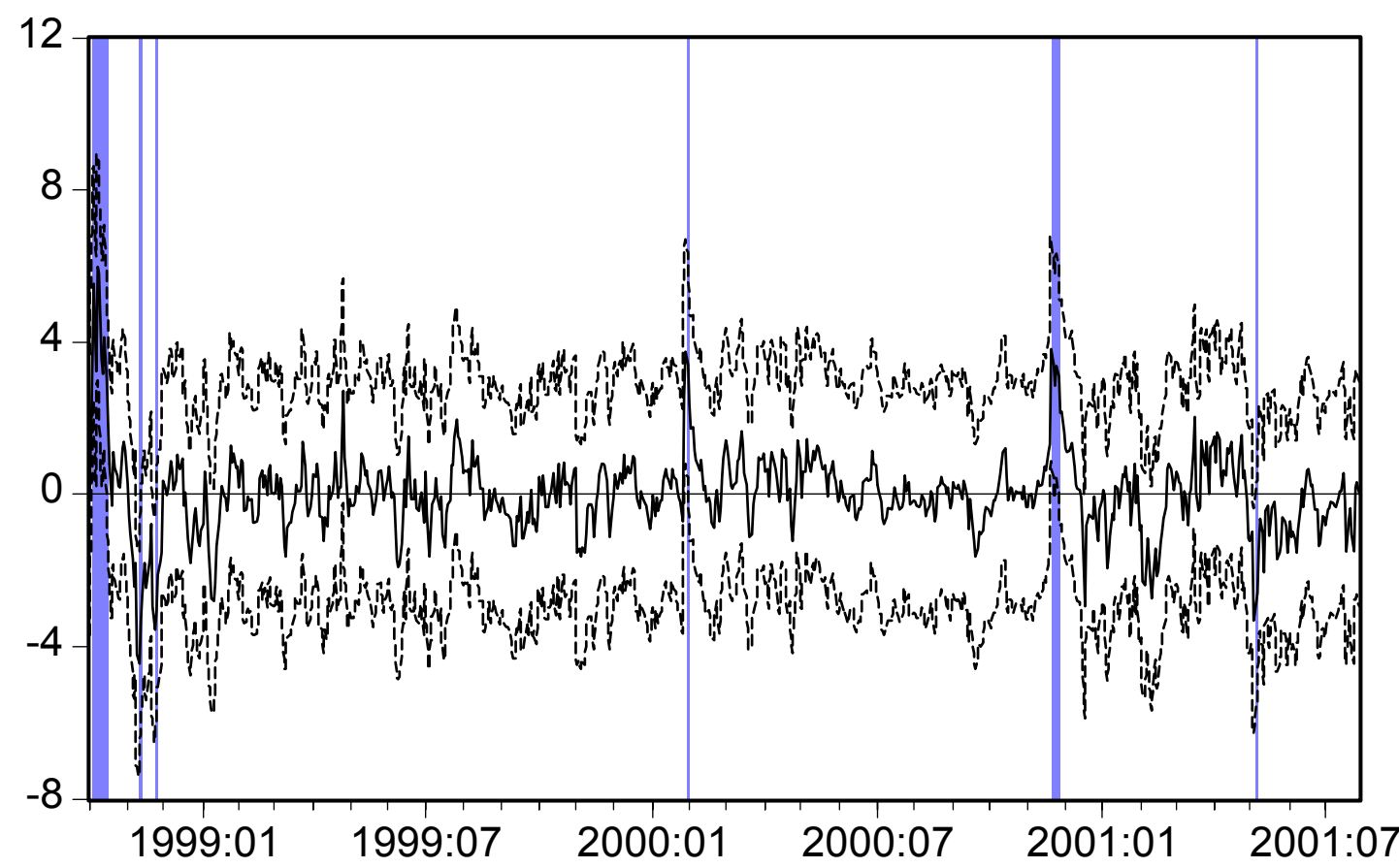

------ Signal-2*rmse _ Risk Signal ------ Signal+2*rmse 
Figure 3

Bank of America/Nations Bank

Comparison of the Risk Signal to Equity and Spreads
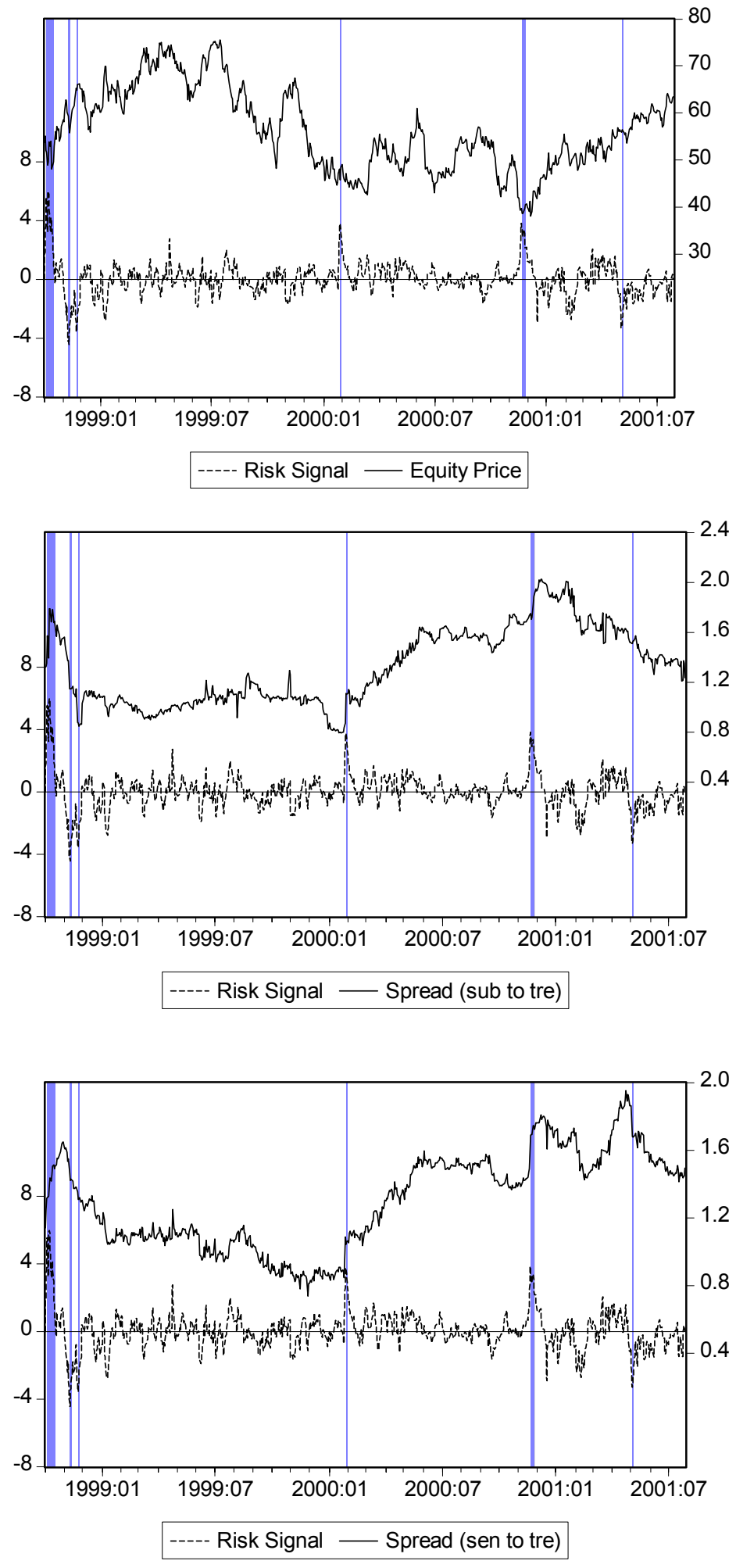


\section{Figure 4}

\section{Bank of America/Nations Bank}

\section{Impulse Response Functions for the Risk Signal from VAR(2)}

\section{Responses to one standard deviation innovation with $95 \%$ confidence bands (Cholesky factorization)}

Response of Return to Risk Signal

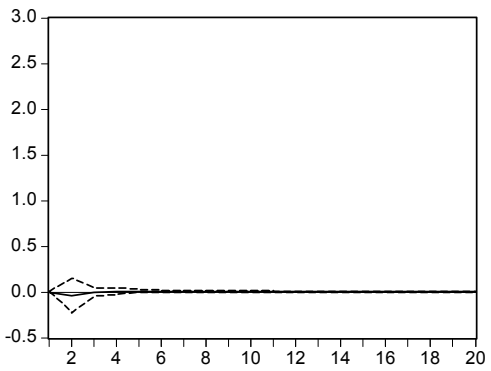

Response of Risk Signal to Return

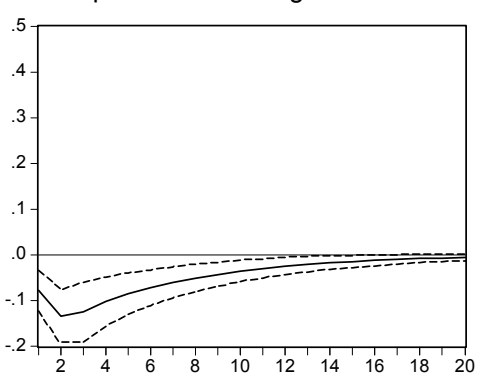

Response of Sub Debt Spread Changes to Risk Signal

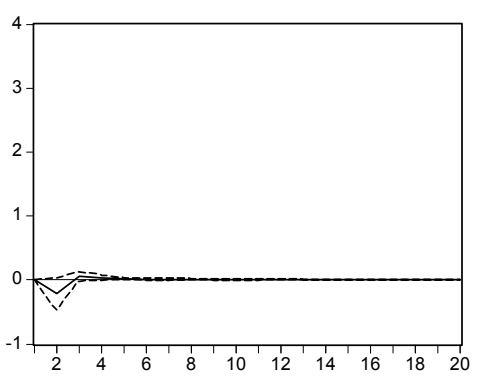

Response of Risk Signal to Sub Debt Spread Changes

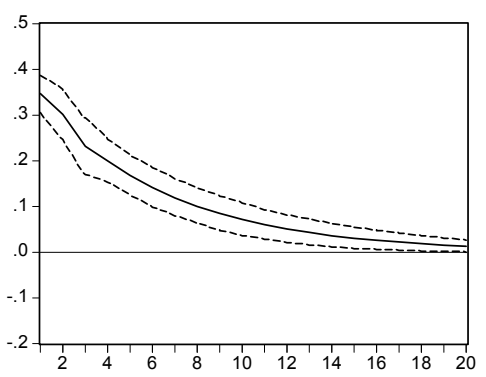

Response of Risk Signal to its own innovations

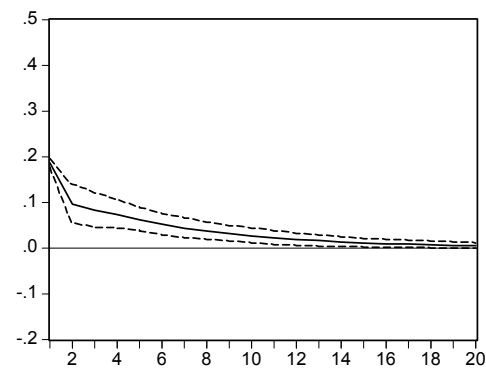

Response of Senior Debt Spread Changes to Risk Signal

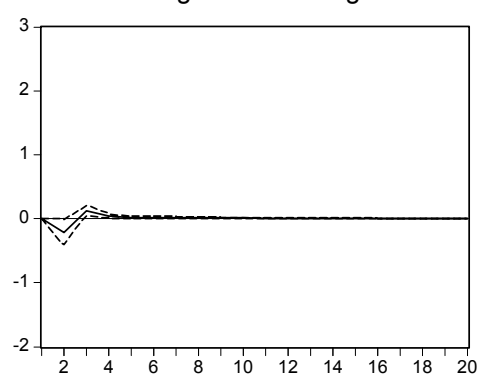

Response of Risk Signal to Senior Debt Spread Changes

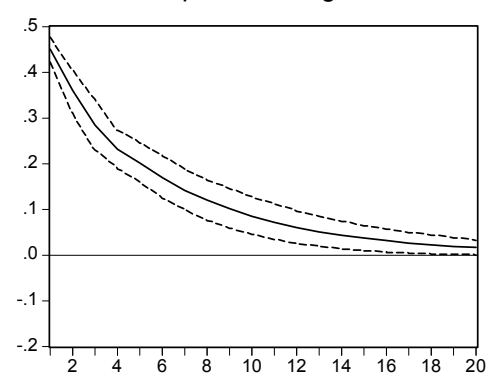


Figure 5

Banker's Trust

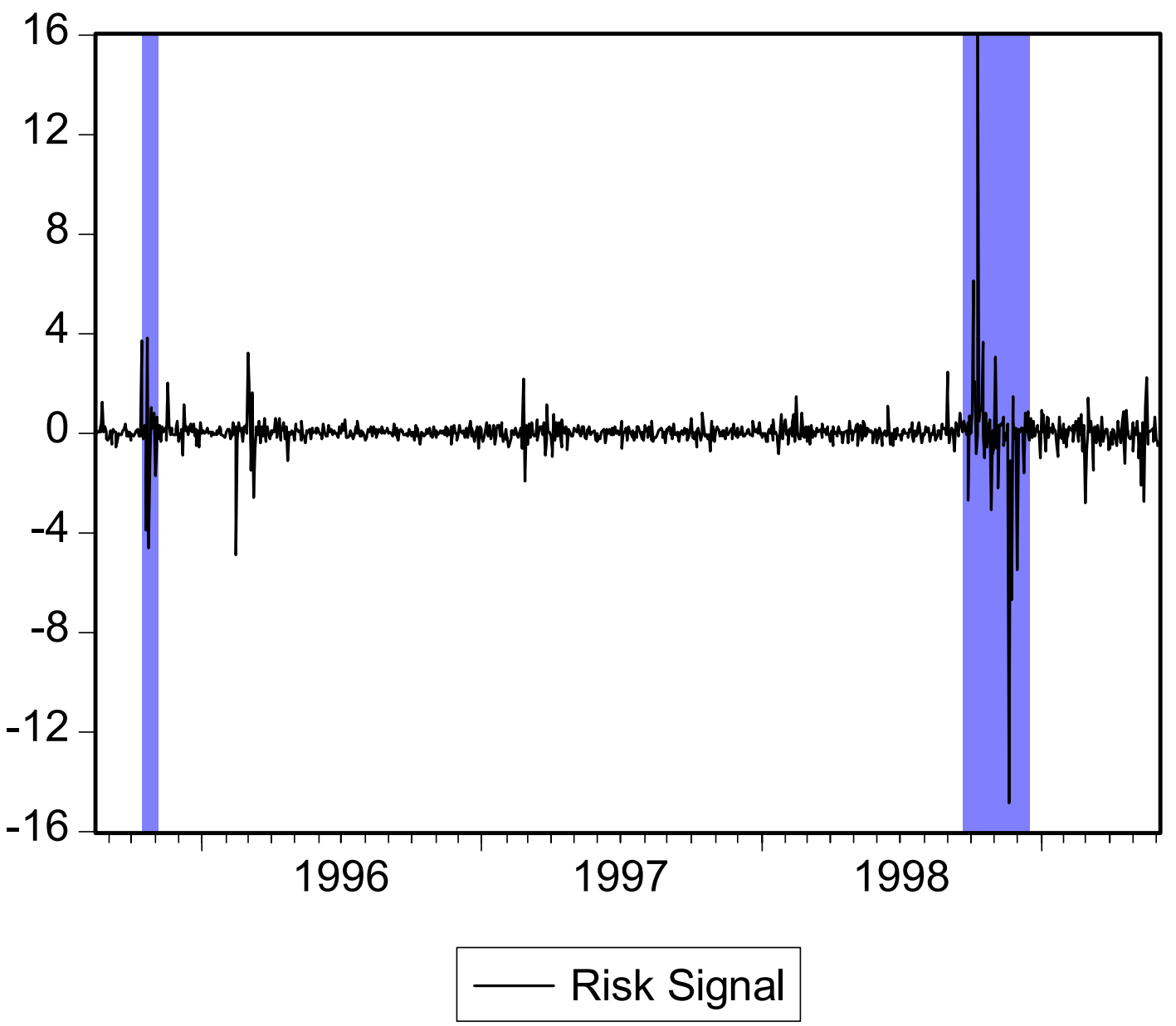

